\title{
Cointegration of Stock Prices and Domestic Portfolio Diversification Opportunities: Evidence from the Ghana Stock Exchange
}

\author{
George Amfo-Antiri ${ }^{1}$, Edward Quansah ${ }^{2}$ \\ ${ }^{1}$ College of Distance Education, University of Cape Coast, Ghana \\ ${ }^{2}$ University of Cape Coast, Department of Finance, Ghana \\ Correspondence: George Amfo-Antiri, College of Distance Education, University of Cape Coast, Ghana.
}

Received: June 12, 2017

doi:10.11114/aef.v4i5.2475

Accepted: August 8, 2017

Available online: August 28, 2017

URL: https://doi.org/10.11114/aef.v4i5.2475

\begin{abstract}
This paper employed Engle-Granger test of cointegration and the Bound Test to explore potential domestic portfolio diversification opportunities that are available for individual investors, institutional and other portfolio managers from constructing domestic portfolios. Daily stock prices for the period $1^{\text {st }}$ August, 2011 to July $29^{\text {th }}$, 2016 have been employed as well as monthly stock return from the Ghana Stock exchange. The result from the cointegration analysis indicated that most equity stocks listed on the Ghana Stock Exchange are not cointegrated with each other in the long run. In addition, majority of the stock returns are statistically insensitive to the GSE-Composite index during the period under consideration. The empirical evidence indicates that domestic investors can benefit from constructing portfolios that consist of equities from the financial sector and other non-financial sectors which are not cointegrated.
\end{abstract}

Keywords: cointegration, domestic portfolio, diversification, stock prices, beta, financial stocks

\section{Introduction}

A recent development in the field of finance and investment has been the recognition that the formation of an optimum investment portfolio can be achieved through combination of a number of securities that do not move in tandem with each other. Hence individual and institutional investors should consider the characteristics of the individual securities as well as their relationship. Khan (2011) posits that one of the fundamental tenants of investing is holding a diversified portfolio of securities and reducing one's exposure to risk. Consequently, fund managers are always on the look-out for securities that do not correlate together and hence provide for better opportunities to hedge risk. Levy and Post (2005) also argue that the basic notion of diversification involves spreading a portfolio over many investments to avoid excessive exposure to a few sources of risk.

The Ghana Stock Exchange like any other emerging capital market exhibits a volatility in returns which is measured by the standard deviation. Frimpong and Oteng-Abayie (2006) revealed that the standard deviation from the databank stock index (DSI) as a proxy for GSE- All Share Index was high, indicating a high level of fluctuations of the DSI daily return. This can be attested to when one observes the returns from the Ghana Stock Exchange All- share index from 1990 to 2016. This suggests that individual assets on the exchange may also portray similar trends. However, if one combines these risky individual securities in a portfolio, it is possible to reduce the overall risk without sacrificing total returns. This is the theory first introduced by Markowitz in 1952. The theory suggests that portfolio returns can be maximized even with very risky assets insofar as there is a low covariance of returns between the risky assets and other assets in the portfolio. Thus to achieve maximum benefit in portfolio diversification, correlations among stock prices or stock markets should be lower than the correlations among stocks within the same industry or market.

Correlation techniques have been employed in the past decades to determine the benefits from diversification (Panton, Lessig, \& Joy, 1976; Ripley, 1973), but recent studies have shifted focus to cointegration analysis. This is due to the fact that correlation reflects co-movement in returns which exhibit great instability over time and is extremely sensitive to short term dynamics. However, cointegration measures long-run co-movement in raw prices. Khan (2011) argues that cointegration of stock prices has a direct impact on diversification opportunities. Therefore, any portfolio investment strategies that basically rely only on volatility and correlation of returns may not lead to long term benefits. Most studies using cointegration have arrived at essentially the same conclusion that there is cointegration between stock prices or stock price indices either internationally or domestically (Georgoutsos \& Kouretas, 2003; Constantinou, 
Kazandjian, Kouratas, \& Tahmazian, 2005; Fraser \& Oyefeso, 2005; Fadhlaoui, Bellalah, Dherry, \& Zouauii, 2009; Khan, 2011; Dasgupta, 2014).

Cointegration analysis enables investors to investigate the long-run properties of stock prices. If cointegration is present, then there is a long-run relationship between the two series. For portfolio diversification, the evidence of cointegration existing between two or more equity prices indicates that these prices are moving together in the same direction in the long run and hence, the benefits from diversification with the formation of a portfolio that includes securities from these equities are limited. However, evidence of no cointegration indicates that there are significant diversification benefits in the long run for investors in terms of reduction of risk without significant loss in the expected returns.

Cointegration of the stock markets has been studied considerably with particular attention on international diversification. Evidently, there is a growing acceptance that there is risk reduction if one undertakes international portfolio diversification (Chukwuogor, 2007). This is essentially true because security prices are less correlated across countries since countries vary in terms of economic, political, industry structure, resources endowment as well as different business cycle (Eun \& Resnick, 2012). Contrary to this assertion, Chavoushi (2010) as cited in Agyapong (2014) found that correlations among country indices increased considerably during the period of closer economic cooperation and integration. However, in consonance with the OLI paradigm (Dunning,1988) which postulates that investors would rather want to undertake investments in their home countries (domestic portfolio diversification) to be able to gain some level of experience before forming portfolio with international dimension, thus it is imperative to examine domestic portfolio diversification. The paper therefore, empirically investigates whether there are some benefits from domestic portfolio diversification in the long run for private and institutional investors investing on the Ghana Stock Exchange (GSE) and also determines the sensitivities of returns from the various equities to the GSE composite index. We believe that the study contributes to literature on financial market by filling the gap on domestic portfolio investment. The rest of the paper is presented as follows. Section 2 presents a brief review of related literature and discussion on the Ghana Stock Exchange. Section 3 presents and discusses the data and methodology. Section 4 discusses the empirical results and analysis. Lastly, section 5 provides the summary and the conclusions.

\section{Literature Review}

In the past, portfolio formation mostly relied on the analysis of correlations among security prices to guide an investor to select appropriate assets to form investment portfolio (see for example Panton et al., 1976; Ripley, 1973). However, in recent years cointegration techniques have been applied to determine the diversification benefits that an investor might obtain.

Constantinou et al. (2005) analysed the potential benefit that domestic investors would get when constructing portfolio investments involving assets that are not cointegrated from the Cyprus Stock Exchange. Their study concluded that there are benefits from portfolio diversification, when domestic investors construct portfolios which include stocks from the sectors which are not cointegrated.

Studies into International portfolio diversifications have received considerable attention lately (Dasguta, 2014; Fadhlaoui et al., 2009; Fraser, \& Oyefeso, 2005; Georgouttsos, \& Kouratas, 2003) with less emphasis on domestic portfolio investment opportunities. The results from these studies are mixed. Using cointegration techniques, Saadi-Sedik and Petri (2006) found that the Amman Stock Exchange (ASE) and other Arab stock markets were cointegrated but no evidence of cointegration was revealed between ASE and other emerging or developed stock markets suggesting that there are long run diversification benefits by investing in the markets that are not integrated.

Khan (2011) investigated the long-run convergence of the United States and 22 other developed and developing countries. The study showed that stock markets of most countries have become cointegrated by 2010 signifying little benefits in constructing portfolios involving these markets. Erdinc and Milla (2009) also find that there exists a long term relationship when capital markets of European countries are matched with each other.

Zafaranloo and Sapian (2013) explored the benefits of international portfolio diversification among five Asian emerging markets (Malaysia, Thailand, Indonesia, China and India) and the United States from 2006 to 2012 and found no evidence of long run relationships among five Asian markets and the US market implying that Us investor can benefit from investing in these markets.

Guidi and Ugur (2014) examined whether the South-Eastern European (SEE) stock markets of Bulgaria, Croatia, Romania, Slovenia and Turkey are integrated with their developed counterparts in Germany, the UK and the USA. The authors employed both static and dynamic cointegration tests. The study revealed that the SEE markets are cointegrated with the German and the UK markets but not with the USA market when static cointegration test is employed. However, the dynamic cointegration analysis suggested an existence of time-varying cointegration among the SEE markets and their developed counterparts.

From the few studies reviewed it could be noticed that attention has been given to international portfolio diversification 
without looking at the benefits one would also get from investing solely in the domestic markets. The study by Constantinou et al. (2005) specifically looked at the domestic portfolio diversification opportunities. Motivated by the this study, the present study was undertaken to look at the benefits investors investing solely in the equities on the Ghana Stock Exchange would get. Our study differs from Constantinou et al. (2005) who used sectoral stocks indices. Our study used individual stock prices to investigate whether there were potential benefits accruing to investors on the Ghana Stock Exchange.

\subsection{The Ghana Stock Exchange}

The Ghana Stock Exchange (GSE) is the primary stock market in Ghana. The Ghana Stock Exchange was given recognition as a stock exchange by Executive Instrument in October, 1990 under the Stock Exchange Act, 1971 (Act 384). The exchange was officially launched on $11^{\text {th }}$ January, 1991 although trading started on $12^{\text {th }}$ November, 1990 with 13 listed companies as at the end of 1991. As at $31^{\text {st }}$ December, 2016 there were 37 listed companies with 40 equities listed on the main board and 4 companies also listed at the GSE Alternative Market (GAX). Out of the 37 companies 14 were financial and 23 were non-financial entities. The Ghana Stock Exchange is adjudged one of the best capital markets in West Africa.

Ghana's stock market has attracted domestic and foreign companies' attention because of its fast development and potential opportunities. The market capitalization for the Exchange as at $31^{\text {st }} \mathrm{July}, 2016$ stood at GHC54605.60 million as against a market capitalization of GH 57,116.87 million in December, 2015 signifying a decrease of about $4.4 \%$. The domestic capitalization rose from GHC6,753.14 million in 2012 to GHC13,868.55 million in 2014 registering an increase of about $105.4 \%$ over the two years. However, the domestic capitalization has decreased by $24.7 \%$ as at the end of July, 2016 (GSE- Market reports, 2013-2016). Table 1 reports the total market and domestic capitalization from year end of 2012 to July, 2016.

Table 1. Total Market and Domestic Capitalization

\begin{tabular}{llllll}
\hline & 2012 & 2013 & 2014 & 2015 & July 2016 \\
YEAR & GHS(M) & GHS(M) & GHS(M) & GHS(M) & GHS(M) \\
\hline TOTAL MARKET CAPITALIZATION & & & & & \\
DOMESTIC CAPITALIZATION & $57,264.22$ & 61158.29 & 64352.42 & 57116.87 & 54605.60 \\
& & & & & \\
& 6753.14 & 11694.93 & 13868.55 & 11185.18 & 10443.75 \\
\hline
\end{tabular}

\section{SOURCE: GSE market reports- 2013-2016}

In 2011, Ghana Stock Exchange introduced two new indices: The GSE COMPOSITE INDEX, a capitalization weighted index, using Volume Weighted Average Price (VWAP) of GSE-listed companies as well as GSE FINANCIAL STOCK INDEX, a capitalization weighted index, using VWAP of GSE-listed financial equities other than equities listed on other markets. The main index is the GSE- Composite Index which is the index for all the equities traded on the Exchange other than equities listed on other markets to replace the GSE ALL SHARE INDEX.

Figure 1 and 2 show the graph of GSE- CI's return from its year of establishment to the year ended 2016. As can be seen from the figure, the stock exchange performance in 2003 was the highest in the history of its establishment. Agyapong (2014) posits that the Exchange achieved its remarkable performance in the year 2003, when the performance of the All-Share Index topped several emerging stock markets. 


\section{Graph of GSE Return from 1990- 2016}

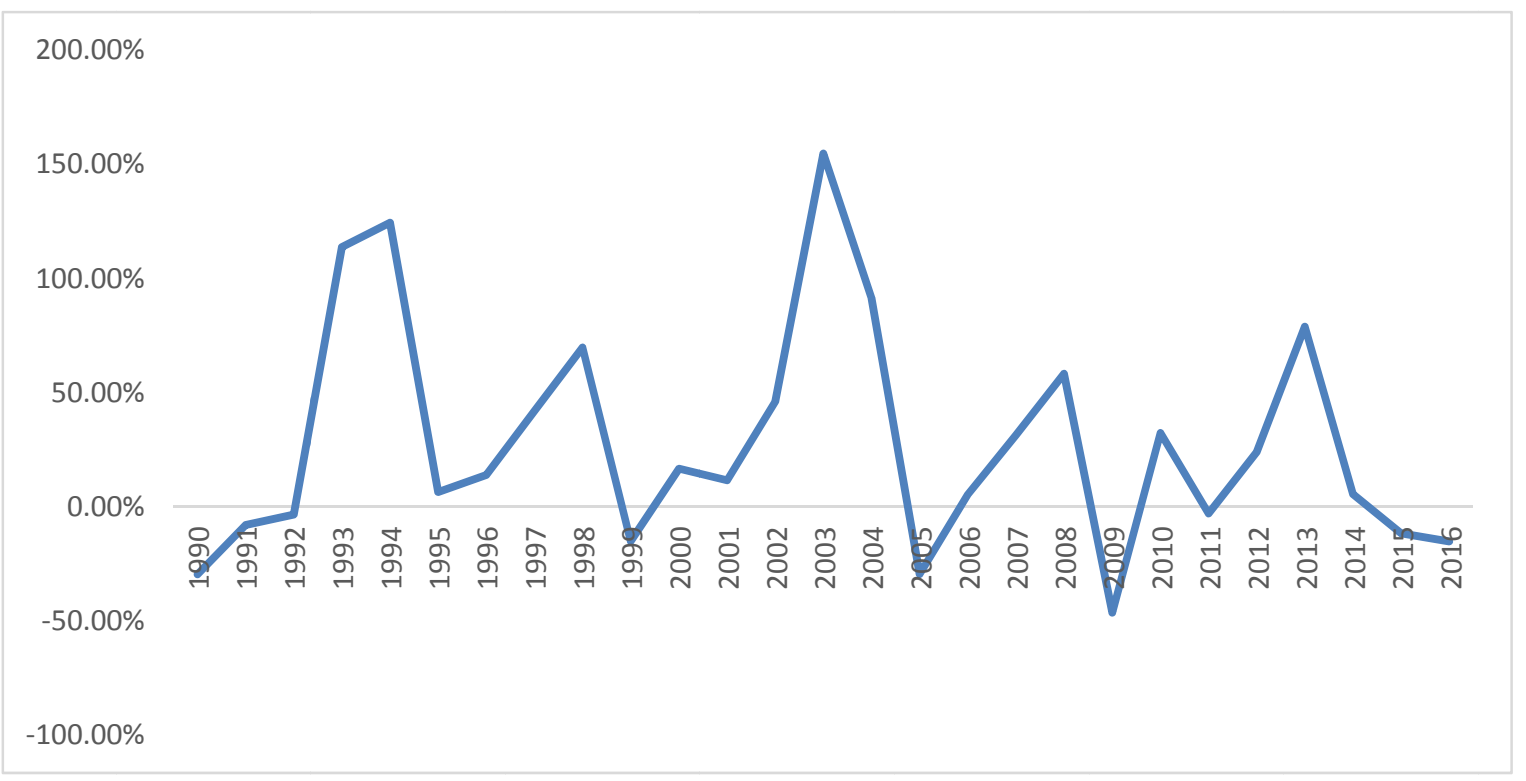

Figure 1. Ghana Stock Exchange Return

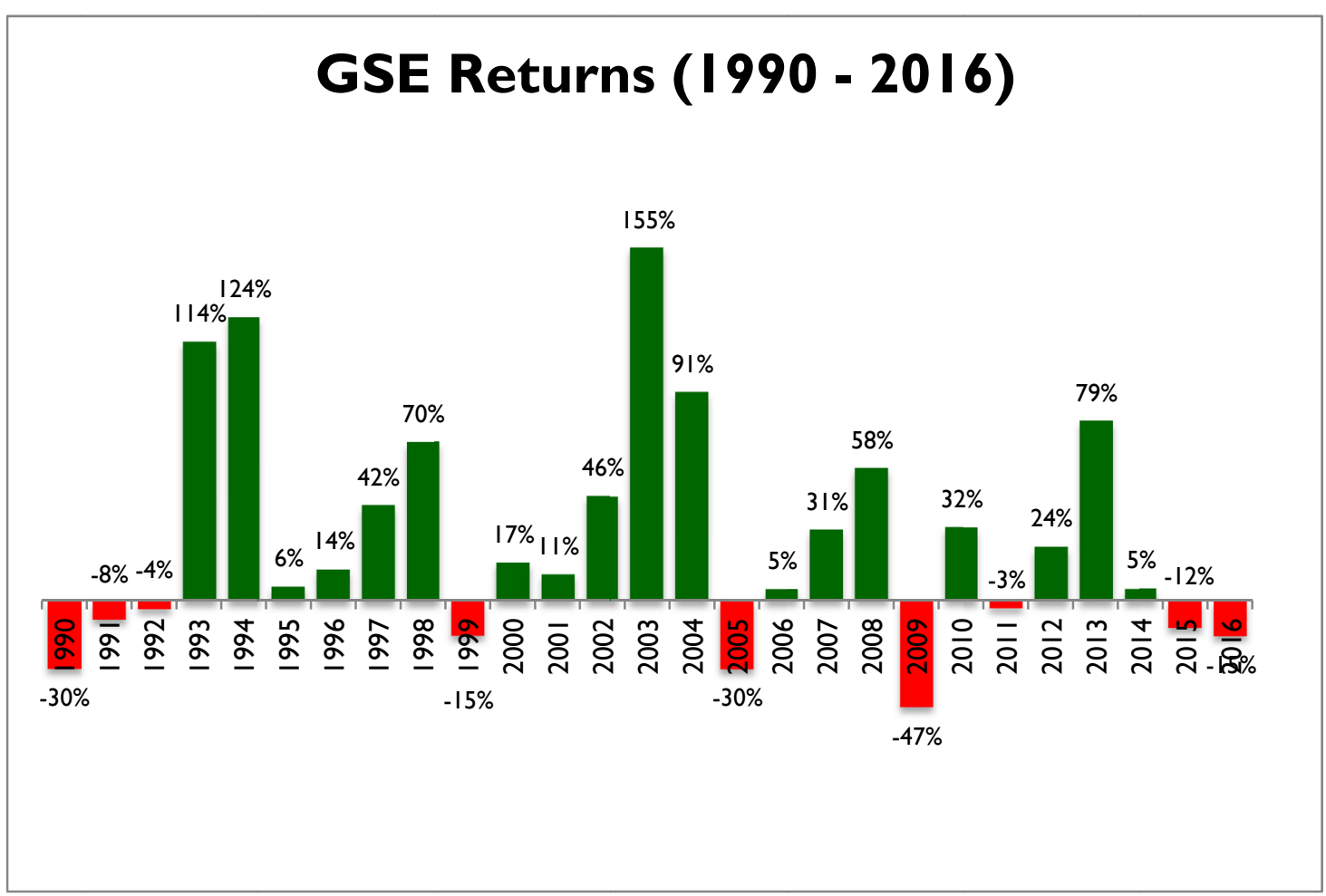

Figure 2. Ghana Stock Exchange Return

Source: ARG- GHANA STOCK EXCHANGE MARKET REPORT 2016.

\subsubsection{The Trend of the GSE-Indices}

The trend of the Ghana stock exchange composite index and financial stock index has been erratic thus exhibiting the bearish and bullish behaviours often seen with emerging markets. Figure 3 shows the trend of the GSE-CI and GSE-FSI from December, 2010 to $31^{\text {st }}$ December, 2016 


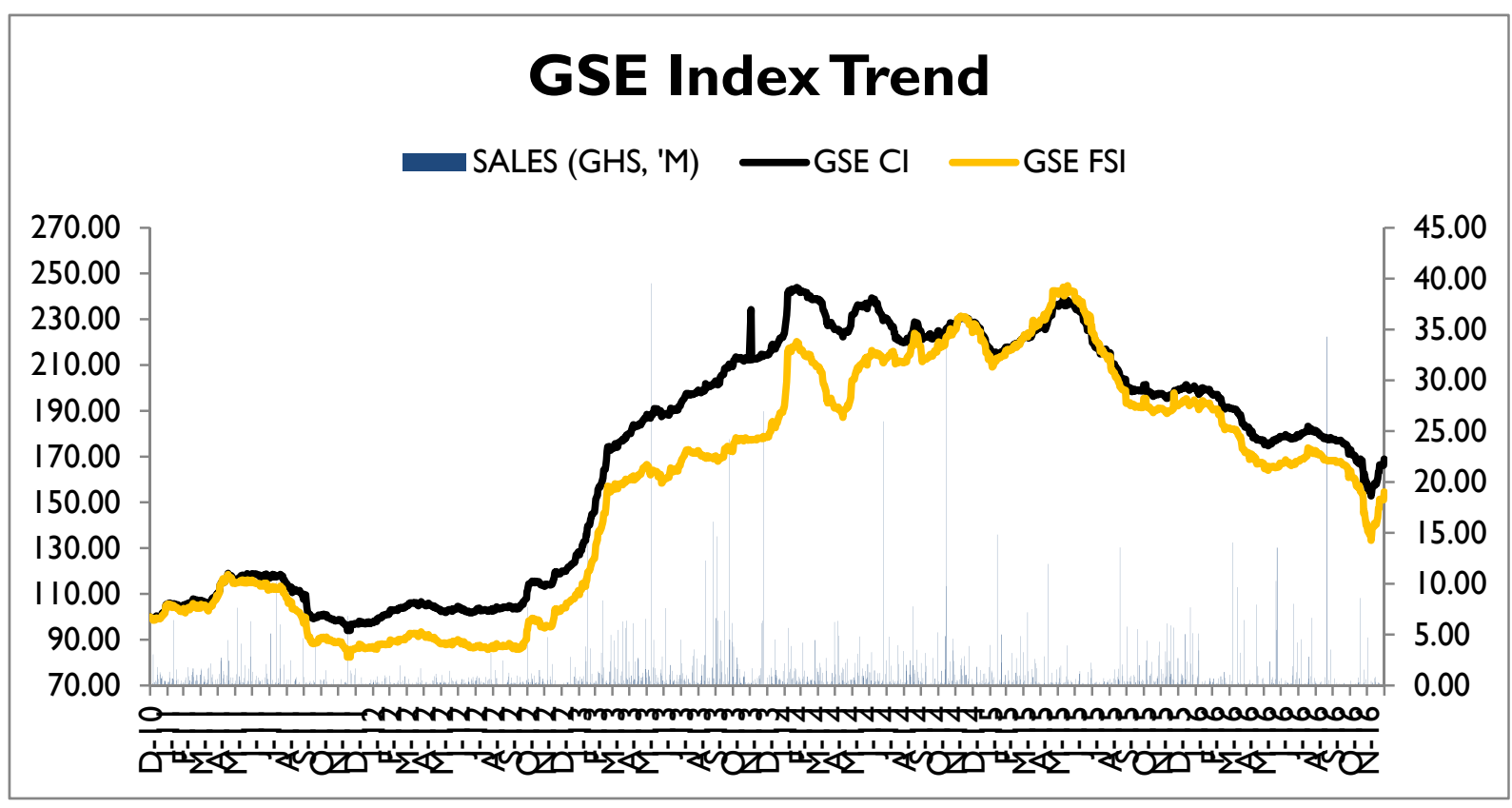

Figure 3. Ghana Stock Exchange (GSE Index Trend)

Source: ANNUAL REPORT GHANA (ARG) MARKET REPORT 2016.

\section{Data and Methodology}

\subsection{Data}

The data for the cointegration analysis consist of daily volume weighted average prices (closing prices) for the financial equities and the non- financial equities. The time frame for the analysis was from $1^{\text {st }}$ August, 2011 to $29^{\text {th }}$ July, 2016. The start date was chosen to be August, 2011 in order to include Tullow Oil Plc. The final sample consists of 1236 observations. The stock prices were extracted from the Ghana Stock Exchange database and all series were transformed into natural logarithms. Companies that were listed on other markets were excluded from the study. For the CAPM analysis we used the GSE- Composite index (All share Index) as the overall market index. The monthly values of the GSE- CI and the individual stock prices were employed. The data for this analysis start from the month of August, 2011 to May, 2017 making 70 observations to estimate the betas ( $\beta \mathrm{s})$. The study includes 28 companies that have complete share prices during the study period as well as meeting the estimation requirements. Appendix A provides the list of companies listed on the GSE as of May, 2017.

\subsection{Empirical Methodology}

In the finance literature it is extensively argued that most of the finance time series display trend and seasonal components over time and can be non-stationary. Their mean values, variances, and covariance of these economic variables change over time. Therefore, regressing one nonstationary variable on another will produce spurious results (Brooks, 2008; Gujrati, 2006). However, the linear combination of these nonstationary time series can be stationary. In such case, the variables are said to be cointegrated. Cointegration implies the existence of a long-run equilibrium between the variables and these variables cannot move independently of each other. We employed two cointegration tests; Engle-Granger test which requires that all variables are of I (1) and autoregressive distributed lag model (ARDL) of Pesaran et al. (2001) which is able to handle regressor variables of $(I(0)$ and/or $I(1))$. Finally, the sensitivities of the returns of the equities to the Ghana Stock Exchange-Composite Index were also analyzed to determine the maximum diversification benefit for risk reduction by employing OLS estimation technique for the Capital Asset Pricing Model (CAPM)

\subsubsection{Engle-Granger Two-Step Cointegration Approach}

The long-run bivariate relationship between pair of variables can be written as:

$$
\begin{aligned}
& y_{t}=\alpha+\beta_{i} x_{t}+\mu_{t} \\
& x_{t}=\alpha+\beta_{i} y_{t}+\mu_{t}
\end{aligned}
$$


Where $x$ and $y$ are the natural logs of stock prices of any two variables in a pair-wise manner.

$\mathrm{t}$ is the time period, $\alpha$ and $\beta$ are the parameters to be estimated and $u_{t}$ is white noise term.

According to Engle-Granger two-step cointegration approach, if $y_{t} \sim I(1)$ and $x_{t} \sim I(1)$ are cointegrated, a linear combination should be stationary, i.e. $y_{t}-\alpha-\beta_{i} x_{t}=\hat{\mu} \sim I(0)$. The parameters $\alpha$ and $\beta_{i}$ are estimated through OLS and $I(0)$ tested with Augmented Dickey-Fuller (ADF).

\subsubsection{The Bound Test}

The study also utilizes the autoregressive distributed lag model (ARDL) of Pesaran et al. (2001) which is applicable irrespective of whether the order of integration of the regressor variables are $(I(0)$ and/or $I(1))$. None of the regressors should however be I (2) and also the dependent variable should be integrated of order 1. However, since the paper examines the cointegration between the variables in a pairwise manner, only I (1) variables were considered. For a pair of $\mathrm{X}$ and $\mathrm{Y}$ variables, ARDL model of order ( $\mathrm{p}, \mathrm{q})$ determined by Schwarz Information Criterion (SIC) is represented as

$$
\Delta Y_{t}=\alpha+\sum_{i=1}^{p} \beta_{i} \Delta Y_{t-i}+\sum_{i=0}^{q} \gamma_{i} \Delta X_{t-i}+\lambda_{1} Y_{t-1}+\lambda_{2} X_{t-1}+\varepsilon_{t}
$$

And for a pair of $\mathrm{X}$ and $\mathrm{Y}$ variables, ARDL model of order $(\mathrm{m}, \mathrm{n})$

$$
\Delta X_{t}=\alpha+\sum_{i=1}^{m} \beta_{i} \Delta X_{t-i}+\sum_{i=0}^{n} \gamma_{i} \Delta Y_{t-i}+\lambda_{1} Y_{t-1}+\lambda_{2} X_{t-1}+\varepsilon_{t}
$$

Where $\lambda_{1}$ and $\lambda_{2}$ are long run coefficients, $\beta$ and $\gamma$ are the short run coefficients, $\alpha$ is the intercept, $\Delta$ denotes difference operator and $\varepsilon_{t}$ is the white noise error term. Optimal lag length for the estimated long-run model is selected on the basis of the Schwarz Information criterion. In equation (4) and (5), the null hypothesis of no-cointegration $H 0: \lambda_{1}=\lambda_{2}=0$ against alternative of existence of cointegration: $\quad H 1: \lambda_{1} \neq \lambda_{2} \neq 0$ is tested using F-statistics. The normalized long- run model is represented as $F Y(Y \mid X)$ and $F X(X \mid Y)$. The calculated $F$-statistics is compared with two sets of critical $5 \%$ values estimated by Pesaran et al. (2001) which is decomposed into lower critical bounds $(I(0))$ and upper critical value bounds $(I(1))$ leads to the appropriate conclusion regarding cointegration. If the calculated $F$-statistic exceeds the upper critical value, the null hypothesis of no cointegration is rejected independent of the order of integration of the series; otherwise we fail to reject the null hypothesis. Computed F-statistic is compared with critical values (Significant at 0.05). Critical Values are cited from Pesaran et al. (2001), Table CI (iii), Case III: Unrestricted intercept and no trend. The models are estimated by the use of E-Views 9.5

\subsubsection{The Capital Asset Pricing Model}

The sensitivities of the returns of the equities to the GSE-CI are analyzed to determine the maximum diversification benefit for risk reduction using the CAPM regression equation of the form

$$
R_{i, t}-r f=\alpha_{i}+\beta_{i}\left(R_{m, t}\right)-r f+u_{i, t}
$$

where $R_{i, t}$ is the return on the stock index or on asset ${ }_{\mathrm{i}}$ at time $\mathrm{t}, \quad r f$ is the risk free rate represented by the 3 month treasury bill rate, $R_{m, t}$ is the return from the GSE-CI at time t, $\alpha_{i}$ and $\beta_{i}$ are the coefficients and $u_{i, t}$ is the error term. Equation (6) can be rewritten as

$$
R_{i}=\alpha+\beta \mathrm{R}_{\mathrm{m}}+u_{t}
$$

Where $R_{i}$ and $\mathrm{R}_{\mathrm{m}}$ are the excess returns for the equity and GSE-CI respectively, $\beta$ is the sensitivity of the ith equity to the GSE-Composite index and $u_{t}$ is the error term.

\section{Analysis and Discussion of Empirical Result}

The main objective of this paper is to empirically test whether there are benefits from domestic portfolio diversification in the long run for private and institutional investors who wish to invest in the Ghana Stock Exchange (GSE) and also determine the sensitivities of returns from the various equities to the GSE composite index. 


\subsection{The Result of Unit Root Test}

Table 2. Result of unit root test in levels

\begin{tabular}{|c|c|c|c|c|c|}
\hline SHARE CODE & $\mathrm{ADF}$ & $\mathrm{PP}$ & SHARECODE & $\mathrm{ADF}$ & $\mathrm{PP}$ \\
\hline \multicolumn{3}{|c|}{ NON-FINANCIAL STOCKS } & LSPL & -2.0646 & -2.4355 \\
\hline LACI & -0.2231 & -0.2203 & LSWL & -0.9317 & -0.8289 \\
\hline LALW & -2.5639 & $-2.5941^{*}$ & LTOTAL & -1.2659 & -1.2791 \\
\hline LAYRTN & -0.3274 & 0.0742 & LTRANSOL & -2.0358 & -2.0517 \\
\hline LBOPP & -2.4510 & -2.3482 & LTLW & -1.3864 & -1.6556 \\
\hline LCLYDS & $-2.6233^{*}$ & $-2.6145^{*}$ & LUNIL & -0.8111 & -0.8524 \\
\hline LCMLT & -1.4461 & -1.4310 & \multicolumn{3}{|c|}{ FINANCIAL STOCKS } \\
\hline LCPC & $-7.0591 * * *$ & $-6.405 * * *$ & LCAL & -1.4161 & -1.4045 \\
\hline LFML & -0.3631 & -0.4731 & LEGL & $-2.939 * *$ & $-3.220 * *$ \\
\hline LGGBL & -1.1379 & -1.1412 & LETI & -1.3647 & -1.4449 \\
\hline LGOIL & -1.6073 & -1.7012 & LGCB & -0.9319 & -1.0051 \\
\hline LGSR & -0.6424 & -0.6403 & LHFC & -1.6161 & -1.5975 \\
\hline LGWEB & 0.5008 & 0.5117 & LSCB & -2.3765 & -2.4115 \\
\hline LMLC & -1.4528 & -1.4403 & LSIC & -0.9545 & -1.1916 \\
\hline LPBC & 1.1501 & 1.0724 & LSOGEG & -1.730 & -1.2553 \\
\hline LPKL & $-2.7114^{*}$ & -2.0003 & LTBL & $-4.884 * * *$ & $-4.883 * * *$ \\
\hline LPZC & -2.413 & -2.4408 & LUTB & 1.2745 & 1.2713 \\
\hline
\end{tabular}

Note: $* * *, * *, *$ denotes $1 \%, 5 \%$ and $10 \%$ significant level, respectively. The null hypothesis is that the series is non-stationary, or contains a unit root. The rejection of the null hypothesis is based on MacKinnon (1996) critical values.

The Table 2 and Table 3 show the results for the ADF and PP test for each of the variables. The ADF and PP tests on the logged time series tell us that we cannot reject the null at the levels for all the variables except CPC, EGL, TBL and CLYDS at least at $10 \%$ level of significance.

Table 3. Result of Unit Root Test in Order 1 ( $1^{\mathrm{ST}}$ Difference)

\begin{tabular}{|c|c|c|c|c|c|}
\hline SHARE CODE & $\mathrm{ADF}$ & PP & SHARE CODE & $\mathrm{ADF}$ & PP \\
\hline \multicolumn{3}{|c|}{ NON-FINANCIAL STOCKS } & $\Delta \mathrm{LSPL}$ & $25.419^{* * *}$ & $-37.304 * * *$ \\
\hline$\triangle \mathrm{LACI}$ & $-35.167 * * *$ & $-35.167 * * *$ & $\Delta \mathrm{LSWL}$ & $-35.139 * * *$ & $-35.458 * * *$ \\
\hline$\triangle \mathrm{LALW}$ & $-35.050 * * *$ & $-35.040 * * *$ & $\triangle$ LTOTAL & $-34.896^{* * *}$ & $-34.896 * * *$ \\
\hline$\triangle$ LAYRTN & $-36.244 * * *$ & $-36.472 * * *$ & $\triangle$ LTRANSOL & $-40.619 * * *$ & $-41.044 * * *$ \\
\hline$\triangle \mathrm{LBOPP}$ & $-16.796 * * *$ & $-35.670 * * *$ & $\Delta \mathrm{LTLW}$ & $-20.405 * * *$ & $-37.519 * * *$ \\
\hline$\triangle \mathrm{LCLYDS}$ & $-32.503 * * *$ & $-53.488 * * *$ & $\triangle \mathrm{LUNIL}$ & $-35.190 * * *$ & $-35.347 * * *$ \\
\hline$\triangle \mathrm{LCMLT}$ & $-23.389 * * *$ & $-39.558 * * *$ & \multicolumn{3}{|c|}{ FINANCIAL STOCKS } \\
\hline$\triangle \mathrm{LCPC}$ & $-38.085^{* * *}$ & $-52.309 * * *$ & $\triangle \mathrm{LCAL}$ & $-23.472 * * *$ & $-39.015 * * *$ \\
\hline$\triangle \mathrm{LFML}$ & $-15.387 * * *$ & $-30.675^{* * *}$ & $\triangle \mathrm{LEGL}$ & $-13.486^{* * *}$ & $-32.304 * * *$ \\
\hline$\Delta \mathrm{LGGBL}$ & $-8.569 * * *$ & $-39.178 * * *$ & $\triangle$ LETI & $-38.799 * * *$ & $-38.661 * * *$ \\
\hline$\Delta$ LGOIL & $-12.904 * * *$ & $-36.594 * * *$ & $\triangle \mathrm{LGCB}$ & $-14.801 * * *$ & $-32.819 * * *$ \\
\hline$\Delta \mathrm{LGSR}$ & $-35.187 * * *$ & $* 35.187 * * *$ & $\triangle \mathrm{LHFC}$ & $-23.428 * * *$ & $-37.282 * * *$ \\
\hline$\triangle \mathrm{LGWEB}$ & $-35.175^{* * *}$ & $-35.175 * * *$ & $\triangle \mathrm{LSCB}$ & $-34.682 * * *$ & $-34.681 * * *$ \\
\hline$\Delta \mathrm{LMLC}$ & $-37.793 * * *$ & $-37.760 * * *$ & $\Delta \mathrm{LSIC}$ & $-22.342 * * *$ & $-34.026 * * *$ \\
\hline$\triangle \mathrm{LPBC}$ & $-34.776 * * *$ & $-34.930 * * *$ & $\triangle \mathrm{LSOGEGH}$ & $-8.621 * * *$ & $-29.618 * * *$ \\
\hline$\triangle \mathrm{LPKL}$ & $-58.434 * * *$ & $-60.166^{* * *}$ & $\Delta \mathrm{LTBL}$ & $-34.946^{* * *}$ & $-34.947 * * *$ \\
\hline$\triangle \mathrm{LPZC}$ & $-35.255 * * *$ & $-35.263 * * *$ & $\triangle \mathrm{LUTB}$ & $-39.760 * * *$ & $-39.879 * * *$ \\
\hline
\end{tabular}

Note: $* * *, * * *$ denotes $1 \%, 5 \%$ and $10 \%$ significant level, respectively. The null hypothesis is that the series is non-stationary, or contains a unit root. The rejection of the null hypothesis is based on MacKinnon (1996) critical values.

On the other hand, we can reject the null for the logged $1^{\text {st }}$ differenced series. All financial and non-financial stock prices that were integrated of order zero i.e. I (0) were removed from the analysis. This means that all the logged time series that were included in the study were integrated of order 1.

\subsection{Cointegration Analysis}

This paper has used daily volume weighted average closing prices of 28 financial and non -financial stocks from the Ghana Stock Exchange. The ADF and PP tests characterized all series as I (1) allowing us to proceed with the cointegration analysis using the Engle - Granger and ARDL cointegration approaches. Tables $4 \mathrm{a}$ and $4 \mathrm{~b}$ present results from the Engle-Granger cointegration analysis and Tables $5 \mathrm{a}$ and $5 \mathrm{~b}$ also present results from the ARDL. The pairs of variables were interchanged in the estimation thus making a total of 756 pairs. Due to large and extensive outputs/results only the summary is reported. 


\subsubsection{Engle-Granger Cointegration Analysis}

As can be seen from the Tables $4 \mathrm{a}$ and $4 \mathrm{~b}$, we did not find any evidence of cointegration among 668 pairs of equities in the sample. However, we found strong evidence of cointegration between the African Champion Industries Ltd and Golden Star Resources Ltd, Starwin Product Ltd and UT bank Ltd. Similarly, a strong cointegration was found amongst African Champion Industries Ltd, Pioneer Kitchen Ware Ltd and Golden Star Resources as well as evidence of long run relationship between Pioneer Kitchen Ware Ltd and Aluworks Ltd, Golden Web Ltd, Tullow Oil Plc, State Insurance Company Ltd and UT Bank Ltd respectively. Evidence of long run relationship was also firmly established amongst Sam Woode Ltd, Total Petroleum Ghana and Transaction Solutions Ltd. Thus portfolio formation involving these equities which have long run relationships may not achieve the desired benefit in the long run. However, we find no cointegration between Benso Oil Palm Plantation and the rest of the sample equities with exception of Ghana Commercial Bank Ltd and Societe General Ghana Ltd. Also, less evidence of cointegration was also found among Guinness Ghana Breweries Ltd, PZ Cussons Ghana Ltd, Total petroleum Ghana Ltd and Tullow Oil Plc among others.

\subsubsection{ARDL Cointegration Result}

The existence of cointegration among the variables was also examined using the ARDL bounds test approach to cointegration analysis. Tables $5 \mathrm{a}$ and $5 \mathrm{~b}$ present results from the ARDL cointegration analysis in a pairwise manner making 378 pairs (756 runs). However, the bound test was able to predict a long run relationships between the 52 pairs out of the 756 runs. The results revealed strong long run relationships between Guinness Ghana Breweries Ltd and HFC Bank Ltd and between HFC Bank Ltd and Unilever Ghana Ltd. Consistent with the Engle- Granger approach, less evidence of cointegration was also found among Ghana Oil Company Ltd (GOIL) Ltd, PZ Cussons Ghana Ltd, Total petroleum Ghana Ltd and Tullow Oil Plc with the other equities. Based on these findings one could achieve a risk reduction in case one constructs a portfolio which includes stocks of the financial sector with stocks from either the Guinness Ghana Breweries Ltd., PZ Cussons Ghana Ltd, Total petroleum Ghana Ltd and Tullow Oil Plc among others. This implies that there will be long-run benefits from the portfolio diversification. The empirical result implies that stock prices do not generally exhibit a long run relationship hence there can be a benefit of domestic portfolio diversification.

Table 4a. Engle-Granger bivariate cointegration analysis

\begin{tabular}{|c|c|c|c|c|c|c|c|c|c|c|c|c|c|c|}
\hline CODE & $\mathrm{ACI}$ & ALW & AYRTN & BOPР & CMLT & FML & GGBL & GOIL & GSR & GWEB & MLC & $\mathrm{PBC}$ & PKL & PZC \\
\hline ALW & NO & - & & & & & & & & & & & & \\
\hline AYRTN & NO & NO & - & & & & & & & & & & & \\
\hline BOPP & NO & NO & NO & - & & & & & & & & & & \\
\hline CMLT & NO & NO & NO & NO & - & & & & & & & & & \\
\hline FML & NO & NO & NO & NO & NO & - & & & & & & & & \\
\hline GGBL & NO & NO & NO & NO & NO & NO & - & & & & & & & \\
\hline GOIL & NO & NO & NO & NO & NO & NO & NO & - & & & & & & \\
\hline GSR & YES & NO & NO & NO & NO & NO & NO & NO & - & & & & & \\
\hline GWEB & NO & NO & NO & NO & NO & NO & NO & NO & $\mathrm{NO} / \mathrm{YES}$ & - & & & & \\
\hline MLC & NO & NO & NO & NO & NO & NO & NO & NO & NO & NO & - & & & \\
\hline PBC & $\mathrm{NO} / \mathrm{YES}$ & NO & NO & NO & NO & NO & NO & NO & NO & NO & NO & - & & \\
\hline PKL & YES & YES & $\mathrm{YES} / \mathrm{NO}$ & NO & YES/NO & $\mathrm{YES} / \mathrm{NO}$ & YES/NO & YES/NO & YES & YES & NO & YES/NO & - & \\
\hline PZC & NO & NO & NO & NO & YES/NO & NO & YES/NO & NO & NO & NO & YES/NO & NO & NO & - \\
\hline SPL & YES & NO & YES/NO & NO & NO & NO & NO & NO & YES & YES/NO & NO & YES & YES & NO \\
\hline SWL & NO & NO & NO & NO & NO & NO & NO & NO & NO & NO & NO & NO & $\mathrm{NO} / \mathrm{YES}$ & NO \\
\hline TLW & NO & $\mathrm{NO} / \mathrm{YES}$ & $\mathrm{YES} / \mathrm{NO}$ & NO & NO & NO & NO & NO & NO & YES/NO & NO & NO & YES & NO \\
\hline TOTAL & NO & NO & NO & NO & NO & NO & NO & NO & NO & NO & NO & NO & NO/YES & NO \\
\hline TRANSOL & NO & NO & NO & NO & NO & $\mathrm{YES} / \mathrm{NO}$ & NO & NO & NO & NO & NO & NO & NO & NO \\
\hline UNIL & NO & NO & NO & NO & NO & NO & NO & NO & NO & NO & NO & NO & $\mathrm{NO} / \mathrm{YES}$ & $\mathrm{NO} / \mathrm{YES}$ \\
\hline CAL & NO & NO & NO & NO & NO & NO & NO & NO & NO & NO & NO & NO & NO & NO \\
\hline ETI & NO & $\mathrm{NO} / \mathrm{YES}$ & NO & $\mathrm{NO} / \mathrm{YES}$ & NO & NO & NO & NO & NO & NO & NO & NO & NO & NO \\
\hline $\mathrm{GCB}$ & NO & $\mathrm{NO} / \mathrm{YES}$ & NO & YES & NO & NO & NO & NO & NO & NO & NO & NO & NO & NO \\
\hline $\mathrm{HFC}$ & NO & NO & NO & NO & NO & NO & NO & NO & NO & NO & NO & NO & NO & NO \\
\hline $\mathrm{SCB}$ & NO & NO & NO & NO & NO & YES/NO & NO & YES/NO & NO & NO & NO & NO & NO & NO \\
\hline SIC & NO & NO & NO & NO & NO & NO & NO & NO & YES/NO & NO & NO & NO & YES & NO \\
\hline SOGEGH & NO & $\mathrm{NO} / \mathrm{YES}$ & NO & YES & NO & NO & NO & YES/NO & NO & NO & NO & NO & NO & NO \\
\hline UTB & YES & NO & NO & NO & NO & NO & NO & NO & $\mathrm{NO} / \mathrm{YES}$ & $\mathrm{NO} / \mathrm{YES}$ & NO & NO & YES & NO \\
\hline
\end{tabular}

Notes: ${ }^{1}$ Yes $=$ the null hypothesis of no cointegration is rejected. No $=$ the null hypothesis of no cointegration is not rejected irrespective of which variable is the dependent variable. 
${ }^{2}$ Yes/No and No/Yes mean that when the dependent variable is column variable and vice versa. The level of significance is $5 \%$.

Table 4b. Engle- Granger bivariate cointegration analysis (Continued from Table 4a)

\begin{tabular}{llllllllllllll}
\hline CODE & SPL & SWL & TLW & TOTAL & TRANSOL & UNIL & CAL & ETI & GCB & HFC & SCB & SIC & SOGEGH \\
\hline SWL & NO/YES & - & & & & & & & & & & & \\
TLW & NO & NO & - & & & & & & & & & & \\
TOTAL & NO/YES & YES & NO & - & & & & & & & & & \\
TRANSOL & NO & YES & NO & YES & - & & & & & & & & \\
UNIL & NO & NO & NO & NO & NO & - & & & & & & & \\
CAL & NO & NO & NO & NO & NO/YES & NO & - & & & & & & \\
ETI & NO & NO & NO & NO & YES & NO & NO & - & & & & & \\
GCB & NO & NO & NO & NO & NO & NO & NO & NO & - & & & & \\
HFC & NO & NO & NO & NO & NO & NO & NO & YES & NO & - & & & \\
SCB & NO & NO & NO & NO & NO & NO & NO & NO & YES/NO & NO & - & & \\
SIC & NO/YES & NO & NO & NO & NO & NO & NO & NO & NO & NO & NO & - & \\
SOGEGH & NO & NO & NO & YES & YES & NO & YES & YES/NO & YES & YES & NO & NO & - \\
UTB & YES & NO & NO & NO & NO & NO & NO & NO & NO & NO & NO & NO & NO \\
\hline
\end{tabular}

Notes: ${ }^{1}$ Yes $=$ the null hypothesis of no cointegration is rejected. No= the null hypothesis of no cointegration is not rejected irrespective of which variable is the dependent variable.

${ }^{2}$ Yes/No and No/Yes mean that when the dependent variable is column variable and vice versa. The level of significance is $5 \%$.

Table 5a. ARDL bound test bivariate cointegration analysis

\begin{tabular}{|c|c|c|c|c|c|c|c|c|c|c|c|c|c|c|}
\hline CODE & $\mathrm{ACI}$ & ALW & AYRTN & BOPP & CMLT & FML & GGBL & GOIL & GSR & GWEB & MLC & PBC & PKL & PZC \\
\hline ALW & NO & - & & & & & & & & & & & & \\
\hline AYRTN & NO & NO & - & & & & & & & & & & & \\
\hline BOPP & NO & NO & NO & - & & & & & & & & & & \\
\hline CMLT & NO & NO & NO & NO & - & & & & & & & & & \\
\hline FML & NO & NO & NO & NO & NO & - & & & & & & & & \\
\hline GGBL & YES/NO & NO & NO & NO & $\mathrm{YES} / \mathrm{NO}$ & YES/NO & - & & & & & & & \\
\hline GOIL & NO & NO & NO & NO & NO & NO & NO & - & & & & & & \\
\hline GSR & NO & NO & NO & NO & NO & NO & NO & NO & - & & & & & \\
\hline GWEB & NO & NO & NO/YES & NO & NO & NO & NO & NO & NO & - & & & & \\
\hline MLC & NO & NO & NO & NO & $\mathrm{YES} / \mathrm{NO}$ & NO & NO & NO & NO & NO & - & & & \\
\hline $\mathrm{PBC}$ & NO & NO & NO & NO & NO & NO & NO/YES & NO & NO & NO & NO & - & & \\
\hline PKL & NO & NO & NO & NO & NO & NO & $\mathrm{NO} / \mathrm{YES}$ & NO & NO & YES/NO & NO & NO & - & \\
\hline PZC & NO & NO & NO & NO & $\mathrm{YES} / \mathrm{NO}$ & NO & YES/NO & NO & NO & NO & $\mathrm{YES} / \mathrm{NO}$ & NO & NO & - \\
\hline SPL & YES/NO & NO & NO & NO & NO & NO & NO & NO & YES/NO & YES/NO & NO & $\mathrm{YES} / \mathrm{NO}$ & NO & NO \\
\hline SWL & NO & NO & NO & NO & NO & NO & $\mathrm{NO} / \mathrm{YES}$ & NO & NO & NO & NO & NO & NO & NO \\
\hline TLW & NO & $\mathrm{YES} / \mathrm{NO}$ & NO & NO & NO & NO & NO & NO & NO & NO & NO & NO & NO & NO \\
\hline TOTAL & NO & NO & NO & NO & NO & NO & $\mathrm{NO} / \mathrm{YES}$ & NO & NO & NO & NO & NO & NO & NO \\
\hline TRANSOL & NO & NO & NO & NO & NO & YES/NO & NO/YES & NO & NO & NO & $\mathrm{YES} / \mathrm{NO}$ & NO & NO & NO \\
\hline UNIL & NO & $\mathrm{YES} / \mathrm{NO}$ & NO & NO & $\mathrm{YES} / \mathrm{NO}$ & NO & NO & NO & NO & NO & $\mathrm{NO} / \mathrm{YES}$ & NO & NO & NO/YES \\
\hline CAL & NO & NO & NO & $\mathrm{NO} / \mathrm{YES}$ & NO & NO & NO & NO & NO & NO & NO & NO & NO & NO \\
\hline ETI & NO & NO & NO & NO & NO & NO & $\mathrm{NO} / \mathrm{YES}$ & NO & NO & NO & NO & NO & NO & NO \\
\hline $\mathrm{GCB}$ & NO & NO & NO & NO & $\mathrm{YES} / \mathrm{NO}$ & NO & NO & NO & NO & NO & NO & NO & NO & NO/YES \\
\hline $\mathrm{HFC}$ & NO & NO & NO & NO & NO & NO & YES & NO & NO & NO & $\mathrm{YES} / \mathrm{NO}$ & NO & NO & NO \\
\hline $\mathrm{SCB}$ & NO & NO & NO & NO & NO & NO & NO & $\mathrm{YES} / \mathrm{NO}$ & NO & NO & NO & NO & NO & NO \\
\hline SIC & NO & NO & NO & NO & NO & NO & NO & NO & NO & NO & NO & NO & $\mathrm{NO} / \mathrm{YES}$ & NO \\
\hline SOGEGH & NO & NO & NO & $\mathrm{NO} / \mathrm{YES}$ & NO & NO & NO & NO & NO & NO & NO & NO & NO & NO \\
\hline UTB & NO & NO & NO & NO & NO & NO & $\mathrm{NO} / \mathrm{YES}$ & NO & NO & NO & NO & NO & $\mathrm{NO} / \mathrm{YES}$ & NO \\
\hline
\end{tabular}

Notes: ${ }^{1}$ Yes $=$ the null hypothesis of no cointegration is rejected. No= the null hypothesis of no cointegration is not rejected irrespective of which variable is the dependent variable.

${ }^{2}$ Yes/No and No/Yes mean that when the dependent variable is column variable and vice versa. The level of significance is $5 \%$. 
Table 5b. ARDL bound test bivariate cointegration analysis (Continued from Table 5a)

\begin{tabular}{|c|c|c|c|c|c|c|c|c|c|c|c|c|c|}
\hline CODE & SPL & SWL & TLW & TOTAL & TRANSOL & UNIL & CAL & ETI & $\mathrm{GCB}$ & $\mathrm{HFC}$ & $\mathrm{SCB}$ & SIC & SOGEGH \\
\hline SWL & $\mathrm{NO} / \mathrm{YES}$ & - & & & & & & & & & & & \\
\hline TLW & NO & NO & - & & & & & & & & & & \\
\hline TOTAL & NO & NO/YES & NO & - & & & & & & & & & \\
\hline TRANSOL & NO & NO & NO & NO & - & & & & & & & & \\
\hline UNIL & YES/NO & YES/NO & NO & NO & NO & - & & & & & & & \\
\hline CAL & NO & NO & NO & NO & $\mathrm{NO} / \mathrm{YES}$ & NO & - & & & & & & \\
\hline ETI & NO & NO & NO & NO & NO & NO & NO & - & & & & & \\
\hline $\mathrm{GCB}$ & NO & NO & NO & NO & NO & NO & NO & NO & - & & & & \\
\hline $\mathrm{HFC}$ & NO & NO & NO & NO & NO & YES & $/ \mathrm{NO}$ & $\mathrm{NO} / \mathrm{YES}$ & YES//NO & - & & & \\
\hline $\mathrm{SCB}$ & NO & NO & NO & NO & NO & NO & NO/YES & NO & NO & NO & - & & \\
\hline SIC & NO & NO & NO & NO & NO & NO & NO & NO & NO & NO & NO & - & \\
\hline SOGEGH & NO & NO & NO & $\mathrm{NO} / \mathrm{YES}$ & NO & NO & YES/NO & NO & YES/NO & $\mathrm{NO} / \mathrm{YES}$ & NO & NO & - \\
\hline UTB & $\mathrm{NO} / \mathrm{YES}$ & NO & NO & NO & NO & NO & NO & NO & NO & NO & NO & NO & NO \\
\hline
\end{tabular}

Notes: ${ }^{1}$ Yes $=$ the null hypothesis of no cointegration is rejected. $\mathrm{No}=$ the null hypothesis of no cointegration is not rejected irrespective of which variable is the dependent variable.

${ }^{2}$ Yes/No and No/Yes mean that when the dependent variable is column variable and vice versa. The level of significance is $5 \%$

\subsection{Analysis of Sensitivity of Returns}

The last part of the paper pertained to finding sensitivity of the returns of stock prices to GSE-CI in order to identify which combination offer the best risk reduction for domestic diversification opportunities.

The monthly mean returns from the stocks range from $-3.22 \%$ to $2.39 \%$ with the mean return of the Ghana Oil company Ltd being the highest whereas Total Petroleum Ghana Ltd was the lowest with a negative return. The Jarque- Bera statistic indicates that most of the data are not normally distributed and therefore it would be appropriate to report their median values. Thus median return was better with Ghana Oil Company Ltd registering the highest return with $2.51 \%$ whiles the least median return was $-1.23 \%$ for the period (see appendix B). Table 6 summarizes the relative risk of each of the stocks. From Table 6, it can be seen that the betas of BOPP, GGBL, GOIL, MLC, UNILEVER, CAL, ETI, GCB, SIC and SOGEGH are significant at $1 \%$ whereas the beta of CMLT, FML, HFC and SCB is significant at $5 \%$. However, the betas of AYRTN, PBC, PZC, TOTAL, TSL and TULLOW are statistically insignificant. None of equities was found to be highly sensitive to the market conditions with a beta value of greater than 1 . It can also be observed that the equity risk associated with most of the assets are less aggressive as well as not highly cointegrated thus forming portfolio with these assets will achieve maximum diversification benefit. Intuitively, more equities are found not to be cointegrated with each other and are also less sensitive or very insensitive to the GSE-CI.

Table 6. Sensitivity of Equities return to the GSE-Composite index

\begin{tabular}{lcllllll}
\hline EQUITY & t- statistics & Beta & P. value & EQUITY & t-stat & Beta & P. Value \\
\hline & NON-FINANCIAL EQUITIES & & SPL & 0.491 & 0.013 & .6249 \\
ACI & -0.288 & -.008 & .7736 & SWL & 0.776 & 0.069 & .4403 \\
ALW & -0.264 & -0.005 & .7922 & TOTAL & 0.617 & 0.012 & .5387 \\
ARTN & -0.058 & -0.005 & .9537 & TSL & -0.476 & -0.052 & .6353 \\
BOPP & 4.426 & 0.166 & $.0000^{* * *}$ & TULLOW & -0.323 & -0.034 & .7476 \\
CMLT & 2.115 & 0.319 & $.0380^{* *}$ & UNILEVER & 3.027 & 0.246 & $.0035^{* * *}$ \\
FML & 2.297 & 0.149 & $.0247^{* *}$ & & FINANCIAL STOCKS & \\
GGBL & 3.807 & 0.205 & $.0003^{* * *}$ & CAL & 2.858 & 0.126 & $.0056^{* * *}$ \\
GOIL & 3.807 & 0.205 & $.0003^{* * *}$ & ETI & 4.967 & 0.173 & $.0000^{* * *}$ \\
GSR & 1.438 & 0.257 & .1545 & GCB & 4.601 & 0.223 & $.0000^{* * *}$ \\
GWEB & -0.382 & -0.019 & .7034 & HFC & 2.358 & 0.118 & $.0212^{* *}$ \\
MLC & 3.317 & 0.152 & $.0015^{* * *}$ & SCB & 2.360 & 0.046 & $.0211^{* *}$ \\
PBC & 1.229 & 0.054 & .2231 & SIC & 3.052 & 0.103 & $.0032^{* * *}$ \\
PKL & -0.156 & -0.029 & .8763 & SOGEGH & 4.110 & 0.172 & $.0001^{* * *}$ \\
PZC & 1.546 & 0.033 & .1267 & UTB & -0.0804 & -0.002 & .9361 \\
\hline
\end{tabular}

Note. $*, * *, * * *$ indicates significant at $1 \%, 5 \%$ and $10 \%$ significant levels respectively 


\section{Summary and Conclusion}

In this paper an attempt has been made to analyze the potential benefits that may be realized from domestic portfolio diversification. Daily data for the period $1^{\text {st }}$ August, 2011 to $29^{\text {th }}$ June, 2016 as well as monthly data from August, 2011 to May, 2017 were used for the cointegration and CAPM analysis respectively. We used cointegration approach to examine whether there are long run bivariate relationships among 28 financial and non- financial stocks in a pair-wise manner. Due to large and extensive set of tables the summary of the results was presented with few appendixes. The study reveals that there are enormous benefits for risk reduction domestically as there is weak evidence of cointegration of security prices. Thus, there are domestic diversification benefits both within the short term and the long run. This evidence can provide some investment insight for individual, institutional and other fund managers such as pension funds, insurance companies and provident funds managers to be able to construct optimum investment portfolios. Though, there are some risk reduction benefits in international portfolio diversification, with the improvement in the information and communication technology (ICT), trade liberalization, regional and international economic cooperation and integration, cross-border capital flows as well as international markets becoming more integrated, the correlation among these markets and economies are becoming more positive, thus the risk reduction benefit from international portfolio diversification is gradually reducing due to this trend. Hence, one could still achieve diversification benefits by investing solely in equities listed on the Ghana Stock Exchange through portfolio investment.

\section{References}

Agyapong, D. (2014). Stock market integration in West African monetary zone: a linear and nonlinear cointegration approach, Asian Economic and Financial Review, 4(5), 563-587.

Annual report Ghana, market data at http://www.annualreportghana.com.

Bank of Ghana, statistical bulletin, Treasury bill rate. www.bog.gov.gh.

Brooks, C. (2008). Introductory Econometrics for Finance ( $2^{\text {nd }}$ Ed.). The ICMA Centre, University of Reading Cambridge university press. https://doi.org/10.1017/CBO9780511841644

Chukwuogor, C. (2007). Stock markets returns and volatilities: A global comparison. Global Journal of Finance and Banking Issues, 1(1), 1-21.

Constantinou, E., Kazandjian, A., Kouretas, G. P., \& Tahmazian, V. (2005). Cointegration, causality and domestic portfolio diversification in the Cyprus Stock Exchange available at www.http://economics.soc.uoc.gr/macro/10 conf/docs/causal.pdf.

Dasgupta, R. (2014). Integration and dynamic linkages of the Indian stock market with BRIC - an empirical study. Asian Economic and Financial Review, 4(6), 715-731.

Dunning, J. H. (1988). The eclectic paradigm of international production: a restatement and some possible extensions. Journal of International Business Studies, 1-31. https://doi.org/10.1057/palgrave.jibs.8490372

Engle, R. F. \& Granger, C. W. J. (1987). Co-Integration and Error Correction: Representation, Estimation, and Testing. Econometrica, 55(2), 251-276. https://doi.org/10.2307/1913236

Erdinc, H., \& Milla, J. (2009). Analysis of cointegration in capital markets of France, Germany and United Kingdom. Economics and Business Journal: Inquiries and Perspectives, 2(1), 109-123.

Eun, S. C., \& Resnick, G. B. (2012). International financial management, ( $6^{\text {th }}$ Ed), Published by McGraw-Hill Irwin.

Fadhlaoui, K., Bellalah, M., Dherry, A., \& Zouaouii, M. (2009). An empirical examination of international diversification benefits in central European emerging equity markets. International Journal of Business, 14(2), 163-173.

Fraser, P., \& Oyefeso, O. (2005). US, UK and European Stock market integration. Journal of Business Finance and Accounting, 32(1-2), 161-181. https://doi.org/10.1111/j.0306-686X.2005.00591.x

Frimpong, M. J., \& Oteng-Abayie, F. E. (2006). Modelling and forecasting volatility of returns on the Ghana Stock Exchange using GARCH models. MPRA Paper No. 593. Available Online at http://mpra.ub.uni-muenchen.de/593/

Georgoutsos, D. A., \& Kouretas, G. P. (2003). Common stochastic trends in international stock markets: Testing in an integrated framework, Department of Economics, Working Paper 01-05, University of Crete.

Ghana Stock Exchange Market reports (2016). Downloaded from http://www.gse.com.gh.

Granger, C. W. J. (1969). Investigating causal relations by econometric models and cross-spectral methods. Econometrica, 37, 424-438. https://doi.org/10.2307/1912791

Guidi, F., \& Ugur, M. (2014). An analysis of South-Eastern European stock markets: Evidence on cointegration and 
portfolio diversification benefit. Journal of International Financial Markets, Institutions and Money, 30, 119-136. https://doi.org/10.1016/j.intfin.2014.01.007

Gujrati, D. N. (2006). Essentials of Econometrics (3rd Ed.). International Edition: McGraw-Hill.

Khan, T. A. (2011). Cointegration of international; stock markets: An investigation of diversification opportunities. Undergraduate Economic Review, 8(1), 1-50.

Levy, H., \& Post, T. (2005). Investments. Harlow: England. Pearson Education.

MacKinnon, J. G. (1996). Numerical Distribution Functions for Unit Root and Cointegration Tests. Journal of Applied Econometrics, 11, 601-618. https://doi.org/10.1002/(SICI)1099-1255(199611)11:6<601::AID-JAE417>3.0.CO;2-T

Markowitz, H. M. (1952). Portfolio selection. The Journal of Finance, 7(1), 77-91. https://doi.org/10.1111/j.1540-6261.1952.tb01525.x

Panton, D. B., Lessig, V. P., \& Joy, O. M. (1976). Comovement of international equity markets: A taxonomic approach. Journal of Financial and Quantitative Analysis, 11(3), 415-432. https://doi.org/10.2307/2330417

Pesaran, M. H., Shin, Y., \& Smith, R. J. (2001). Bounds testing approaches to the analysis of level relationships. Journal of Applied Econometrics, 16(3), 289-326. https://doi.org/10.1002/jae.616

Phillips, P. C. B., \& Perron, P. (1988). Testing for a unit root in time series regression. Biometrika, 75, 335-346. https://doi.org/10.1093/biomet/75.2.335

Ripley, D. M. (1973). Systematic elements in the linkage of national stock market indices. Review of Economics and Statistics, 55(3), 356-361. https://doi.org/10.2307/1927959

Saadi-Sedik, T., \& Petri, M. (2006). The Jordanian stock market- Should you invest in it for risk diversification or performance? IMF working paper, WP/06/187, 1-38.

Zafaranloo, F. R., \& Sapian, R. Z. Z. (2013). The benefit of international portfolio diversification in Asian emerging markets to the US investor. International Journal of Business, Economics and Law, 2(2), 35-42. 
Appendix A. List of Companies listed on the Ghana Stock Exchange as at $31^{\text {st }}$ May, 2017

\begin{tabular}{|c|c|c|c|}
\hline $\mathrm{S} / \mathrm{N}$ & Company & Share Code & Date Listed \\
\hline \multicolumn{4}{|c|}{ NON-FINANCIAL STOCK COMPANIES } \\
\hline 1 & African Champion Industries Limited & $\mathrm{ACI}$ & May 12, 1992 \\
\hline 2 & Anglogold ashanti limited & AGA & April 272004 \\
\hline 3 & Aluworks Limited & ALW & 29th November, 1996 \\
\hline 4 & Ayrton Drugs Manufacturing Co. Ltd. & AYRTN & 14th August, 2006 \\
\hline 5 & Benso Oil Palm Plantation Limited & BOPP & 16th April, 2004 \\
\hline 6 & Clydestone (Ghana) Limited & CLYD & 19th May, 2004 \\
\hline 7 & Camelot Ghana Limited & CMLT & 17th September, 1999 \\
\hline 8 & Cocoa Processing Company Limited & $\mathrm{CPC}$ & 14th February, 2003 \\
\hline 9 & Fan Milk Limited & FML & 18th October, 1991 \\
\hline 10 & Guinness Ghana Breweries Limited & GGBL & 23rd August, 1991 \\
\hline 11 & Ghana Oil Company Limited & GOIL & November 16, 2007 \\
\hline 12 & Golden Star Resources Limited & GSR & 15th February, 2008 \\
\hline 13 & Golden Web Limited & GWEB & August 29th, 2005 \\
\hline 14 & Mechanical Lloyd Company Limited & MLC & 10th May, 1994 \\
\hline 15 & Produce Buying Company Limited & $\mathrm{PBC}$ & May 17 th, 2000 \\
\hline 16 & Pioneer Kitchenware Limited & PKL & August 25th, 1995 \\
\hline 17 & PZ Cussons Ghana Limited & $\mathrm{PZC}$ & August 23rd, 1991 \\
\hline 18 & Starwin Products Limited & SPL & 29th December, 2004 \\
\hline 19 & Sam Woode Limited & SWL & April 24, 2002 \\
\hline 20 & Tullow Oil Plc & TLW & 27th July, 2011 \\
\hline 21 & Total Petroleum Ghana Limited & TOTAL & 19th July, 1991 \\
\hline 22 & Transol Solutions Ghana Limited & TRANSOL & 29th December, 2006 \\
\hline 23 & Unilever Ghana Limited & UNIL & August 23,1991 \\
\hline \multicolumn{4}{|c|}{ FINANCIAL STOCK COMPANIES } \\
\hline 24 & Access Bank Ghana & ACCESS & December, 2016 \\
\hline 25 & Agricultural development Bank & $\mathrm{ADB}$ & December 12,2016 \\
\hline 26 & CAL Bank Limited & CAL & 5th November, 2004 \\
\hline 27 & Ecobank Ghana Limited & EGH & July, 2006 \\
\hline 28 & Enterprise Group Limited & EGL & Feb 21, 1992 \\
\hline 29 & Ecobank Transnational Incorporated & ETI & 11th September, 2006 \\
\hline 30 & GCB Bank Limited & $\mathrm{GCB}$ & 17th May. 1996 \\
\hline 31 & HFC Bank (Ghana) Limited & HFC & 17th March. 1995 \\
\hline 32 & Mega African Capital Limited & MAC & April 23rd, 2014 \\
\hline 33 & Standard Chartered Bank (GH) Ltd. & SCB & August 23, 1991 \\
\hline 34 & SIC Insurance Company Limited & SIC & 25th January, 2008 \\
\hline 35 & Societe Generale Ghana Limited & SOGEGH & October 13th, 1995 \\
\hline 36 & Trust Bank (Gambia) Limited & TBL & November $15^{\text {th }} 2002$ \\
\hline 37 & UT Bank Ghana Limited & UTB & November $25^{\text {th }} 2008$ \\
\hline
\end{tabular}


Appendix B. Monthly Stock Returns from August 2011-MAY 2017

\begin{tabular}{|c|c|c|c|c|c|}
\hline Share Code & MEAN & MEDIAN & STD DEV & MAXIMUM & MINIMUM \\
\hline \multicolumn{6}{|c|}{ NON FINANCIAL STOCKS } \\
\hline $\mathrm{ACI}$ & -2.97 & 0.00 & 17.30 & 69.31 & -69.31 \\
\hline ALW & -0.09 & 0.00 & 25.73 & 69.31 & -87.55 \\
\hline AYRTN & -0.67 & 0.00 & 6.07 & 18.23 & -32.54 \\
\hline BOPP & 2.13 & 0.28 & 12.36 & 52.70 & -30.54 \\
\hline CMLT & 0.12 & 0.00 & 3.32 & 8.70 & -15.41 \\
\hline FML & 1.89 & 0.56 & 7.94 & 32.73 & -26.24 \\
\hline GGBL & 0.01 & 0.00 & 8.85 & 21.51 & -37.06 \\
\hline GOIL & 2.39 & 2.51 & 10.38 & 26.91 & -40.95 \\
\hline GSR & -0.61 & 0.00 & 2.87 & 0.00 & -16.20 \\
\hline GWEB & -1.98 & 0.00 & 10.07 & 0.00 & -69.31 \\
\hline MLC & 0.14 & 0.00 & 10.71 & 43.08 & -22.31 \\
\hline $\mathrm{PBC}$ & -2.78 & 0.00 & 11.76 & 23.36 & -40.55 \\
\hline PKL & -0.48 & 0.00 & 2.83 & 0.00 & -18.23 \\
\hline $\mathrm{PZC}$ & -2.77 & 0.00 & 24.45 & 43.67 & -180.55 \\
\hline SPL & -0.57 & 0.00 & 18.95 & 69.31 & -69.31 \\
\hline SWL & 0.99 & 0.00 & 5.90 & 40.55 & 0.00 \\
\hline TLW & -0.56 & 0.00 & 4.91 & 15.15 & -17.04 \\
\hline TOTAL & -3.22 & 0.00 & 27.02 & 40.63 & -208.28 \\
\hline TRANSOL & -0.99 & 0.00 & 4.80 & 0.00 & -28.77 \\
\hline UNIL & 0.25 & 0.05 & 6.03 & 16.02 & 21.94 \\
\hline \multicolumn{6}{|c|}{ FINANCIAL STOCKS } \\
\hline CAL & 1.45 & 0.00 & 11.39 & 38.48 & -42.57 \\
\hline ETI & -0.34 & 0.00 & 13.04 & 40.55 & -28.77 \\
\hline GCB & 0.81 & 0.27 & 9.59 & 30.77 & -21.72 \\
\hline $\mathrm{HFC}$ & 0.51 & 0.00 & 10.12 & 33.02 & -27.00 \\
\hline $\mathrm{SCB}$ & -1.88 & -0.04 & 26.09 & 42.07 & -195.83 \\
\hline SIC & -2.01 & -1.23 & 14.67 & 63.60 & -43.29 \\
\hline SOGEGH & 0.63 & 0.00 & 11.29 & 37.55 & -41.55 \\
\hline UTB & -2.30 & 0.00 & 17.65 & 40.55 & -69.31 \\
\hline
\end{tabular}


Appendix C. Summary of Augmented Dickey-Fuller Test on residuals (Engle-Granger)

\begin{tabular}{|c|c|c|c|c|c|c|c|c|c|c|c|c|}
\hline \multicolumn{2}{|c|}{ SHARE CODE } & \multirow{2}{*}{$\begin{array}{l}\text { BOPP } \\
-2.135\end{array}$} & \multirow[t]{2}{*}{ FML } & \multirow[t]{2}{*}{ GOIL } & \multirow[t]{2}{*}{ MLC } & \multirow[t]{2}{*}{$\mathrm{PZC}$} & \multirow[t]{2}{*}{ TOTAL } & \multirow[t]{2}{*}{ UNIL } & \multirow[t]{2}{*}{ CAL } & \multirow[t]{2}{*}{ GCB } & \multirow[t]{2}{*}{ HFC } & \multirow[t]{2}{*}{ SIC } \\
\hline FML & t-statistics & & & & & & & & & & & \\
\hline & P. Value & .2307 & & & & & & & & & & \\
\hline \multirow[t]{2}{*}{ GOIL } & t-statistics & -1.954 & -2.616 & & & & & & & & & \\
\hline & P. Value & .3075 & .0898 & & & & & & & & & \\
\hline \multirow[t]{2}{*}{ MLC } & t-statistics & -1.898 & -1.149 & -0.954 & & & & & & & & \\
\hline & P. Value & .3333 & .6980 & .7708 & & & & & & & & \\
\hline \multirow[t]{2}{*}{$\mathrm{PZC}$} & t-statistics & -2.200 & -2.508 & -1.325 & -2.343 & & & & & & & \\
\hline & P. Value & .2062 & .1137 & .6194 & .1585 & & & & & & & \\
\hline \multicolumn{2}{|c|}{ TOTAL t-statistics } & -2.162 & -2.132 & -1.912 & -1.425 & -2.508 & & & & & & \\
\hline & P. Value & .2205 & .2320 & .3268 & .5711 & .1135 & & & & & & \\
\hline \multirow[t]{2}{*}{ UNIL } & t-statistics & -2.108 & -0.113 & -1.258 & -2.095 & -3.001 & -1.171 & & & & & \\
\hline & P. Value & .2414 & .9461 & .6507 & .2465 & $.0350 * *$ & .6886 & & & & & \\
\hline \multirow[t]{2}{*}{ CAL } & t-statistics & -2.595 & -1.846 & -1.801 & -1.549 & -2.602 & -2.075 & -0.510 & & & & \\
\hline & P. Value & .0940 & .3582 & .3798 & .5081 & .0927 & .2547 & .8867 & & & & \\
\hline \multirow[t]{2}{*}{ GCB } & t-statistics & -3.565 & -0.725 & -1.770 & -2.485 & -2.693 & -1.478 & -0.984 & -2.602 & & & \\
\hline & P. Value & $.0066 * * *$ & .8382 & .3953 & .1192 & .0755 & .5445 & .7606 & .0926 & & & \\
\hline \multirow[t]{2}{*}{$\mathrm{HFC}$} & t-statistics & -1.967 & -1.030 & -0.836 & -1.343 & -2.472 & -2.085 & -0.611 & -1.292 & -1.690 & & \\
\hline & P. Value & .3016 & .7441 & .8079 & .6109 & .1226 & .2506 & .8655 & .6351 & .4357 & & \\
\hline \multirow[t]{2}{*}{ SIC } & t-statistics & -1.859 & -1.487 & -1.639 & -1.589 & -2.390 & -1.696 & -1.747 & -1.162 & -0.917 & -1.160 & \\
\hline & P. Value & .3518 & .5396 & .4619 & .4875 & .1445 & .4327 & .4072 & .6925 & .7829 & .6933 & \\
\hline \multirow[t]{3}{*}{ UTB } & t-statistics & -2.227 & 0.296 & -1.895 & -1.441 & -2.487 & -2.146 & -1.113 & -1.281 & -0.762 & -1.014 & -2.456 \\
\hline & P. Value & .1967 & .9781 & .3346 & .5631 & .1188 & .2265 & .7123 & .6402 & .8285 & .7499 & .1267 \\
\hline & & 10 & -3. & 354 & & & & & & & & \\
\hline \multirow[t]{2}{*}{ Test crit } & al values & $\%$ & -2.8 & 636 & & & & & & & & \\
\hline & & $0 \%$ & -2.5 & 679 & & & & & & & & \\
\hline
\end{tabular}


Appendix D. ARDL Bound Test

\begin{tabular}{lllllllllllll}
\hline SHARE CODE & BOPP & FML & GGBL & GOIL & MLC & PZC & TOTAL & UNIL & CAL & GCB & HFC & SIC \\
\hline FML & 3.01 & - & & & & & & & & & \\
GGBL & 3.13 & 0.47 & - & & & & & & & & \\
GOIL & 3.03 & 4.50 & 3.43 & - & & & & & & & & \\
MLC & 3.73 & 0.49 & 2.84 & 1.39 & - & & & & & & & \\
PZC & 3.02 & 3.80 & 1.83 & 4.13 & 1.15 & - & & & & & & \\
TOTAL & 4.23 & 0.10 & $7.07^{* *}$ & 1.46 & 2.40 & 2.99 & - & & & & & \\
UNIL & 3.49 & 0.38 & 0.51 & 1.52 & $5.89^{* *}$ & $5.88^{* *}$ & 1.19 & - & & & & \\
CAL & 5.69 & 1.16 & 4.46 & 1.30 & 1.39 & 5.59 & 5.52 & 2.12 & - & & & \\
GCB & 5.12 & 1.02 & 4.42 & 1.31 & 1.25 & $6.45^{* *}$ & 2.68 & 3.72 & 3.49 & - & & \\
HFC & 3.56 & 0.33 & $13.36^{* *}$ & 1.85 & 3.53 & 3.13 & 1.59 & $7.87^{* *}$ & 2.09 & 0.44 & - & \\
SIC & 3.87 & 2.54 & 3.43 & 1.92 & 1.41 & 2.99 & 1.19 & 0.33 & 1.04 & 0.55 & 5.01 & - \\
UTB & 3.37 & 0.07 & $8.86^{* *}$ & 1.31 & 3.57 & 3.26 & 1.41 & 4.63 & 2.14 & 1.74 & 2.70 & 3.55 \\
\hline
\end{tabular}

Note: Dependent Variables are the Row Headings and independent Variables are the Column Headings

Computed F-statistic is compared with critical values (Significant at 0.05). Critical Values are cited from Pesaran et al. (2001),

Table CI (iii), Case III: Unrestricted intercept and no trend.

Critical Value Lower Bound Value Upper Bound Value

$1 \%$
$5 \%$

6.84

7.84

$10 \%$

4.94

5.73

4.04

4.78

\section{Copyrights}

Copyright for this article is retained by the author(s), with first publication rights granted to the journal.

This is an open-access article distributed under the terms and conditions of the Creative Commons Attribution license which permits unrestricted use, distribution, and reproduction in any medium, provided the original work is properly cited. 